\title{
Mean Performance and Analysis of Variance of Thirty Genotypes for Twelve Characters Studied in Maize (Zea mays L.)
}

\section{Dan Singh Jakhar*, Rajesh Singh, Aneesh Kumar Chandel, Chandan Kumar and Vivek Kumar Ojha}

\author{
Department of Genetics and Plant Breeding, Institute of Agricultural Sciences, \\ Banaras Hindu University, Varanasi - 221005, UP, India \\ *Corresponding author
}

\begin{abstract}
A B S T R A C T
Keywords

Mean performance, Analysis of

Variance, RBD,

Zea mays $\mathrm{L}$

Article Info

Accepted:

20 March 2017

Available Online:

10 April 2017

The mean performance and analysis of variance (ANOVA) was studied in a set of thirty genotypes on maize (Zea mays L.). The experiment was conducted in a Randomized Block Design (RBD) with three replications at Genetics and Plant Breeding Research Farm, Institute of Agricultural Sciences, Banaras Hindu University, Varanasi. The data were recorded on plant height $(\mathrm{cm})$, days to $50 \%$ tasselling, days to $50 \%$ silking, days to $75 \%$ brown husk , ear height $(\mathrm{cm})$, leaf width $(\mathrm{cm})$, tassel length $(\mathrm{cm})$, cob length with husk $(\mathrm{cm})$, cob length without husk $(\mathrm{cm})$, cob diameter $(\mathrm{cm}), 100$ seed weight $(\mathrm{g})$, and grain yield per plant $(\mathrm{g})$. The genotype HUZM-53 produced high grain yield per plant followed by HUZM-185, V-336, HUZM-97-1-2, V-348 and HUZM-80-1. The genotype HUZM478, HUZM-509 and CML-163 were found to be the earliest to tasseling, silking and 75 per cent brown husk. The analysis of variance of twelve characters among 30 genotypes exhibited highly significant differences for all the traits indicating presence of significant variability among 30 genotypes. The presence of variability in present investigation indicated the ample scope of selection for these traits.
\end{abstract}

\section{Introduction}

Maize is an important staple food in many parts of the world. In India maize crop stand up as the third cash crop after wheat and rice. Maize, which is the only food cereal crop that can be grown in different seasons requires moderate climate for growth. It is grown from latitude $58 \mathrm{~N}$ to $40 \mathrm{~S}$, from sea level to higher than $3000 \mathrm{~m}$ altitude and in areas receiving yearly rainfall of 250 to $5000 \mathrm{~mm}$ (Downsell et al., 1996). India had produced only 15.5 million tonnes maize in 2015-16 Kharif season, down from 17.01 million tonnes a year ago, according to the farm ministry data. India's Kharif maize acreage was at 1.15 million hectares as of 23rd June 2016, down $12 \%$ from a year-ago level, according to data from the agriculture ministry. It is used as an important raw material in food processing, feed industry and in various other industrial applications. In the last few years, maize is increasingly being used for feed consumption. Thereby, assuming almost steady demand and reasonable price, the total maize consumption for 2016-17 for feed is likely to rise to 13000 thousand metric tonnes compared to 2015-16 estimated consumption of 12700 thousand metric tonnes. As well, based on latest market reports the poultry industry has been growing 
at 4-5 percent in the last few years. About 65$70 \%$ of maize produced in the country is used by the poultry, livestock, food and starch industries. Improvement in yield and quality of crop is the primary objective of a plant breeder. Selection of superior plants is the basis of crop improvement. The efficiency of selection depends on the identification of genetic variability from the phenotypic expression of the characters. Variability means difference among the individuals of a same or different species. The variability may be due to environment or genotypes or interaction of both the components.

\section{Materials and Methods}

\section{Experimental material}

The experimental materials consisted of 30 genotypes of maize which were obtained from my supervisor Prof. Rajesh Singh, Maize Breeder in Department of Genetics and Plant Breeding, Institute of Agricultural Sciences, Banaras Hindu University, Varanasi.

\section{Experimental design}

The experiment was laid out in randomized block design. The field was divided into three homogeneous replication blocks. Thirty genotypes were randomly planted in three replications. Each entry was represented by a double row of $4 \mathrm{~m}$ length spaced at $75 \mathrm{~cm}$ between the rows and $20 \mathrm{~cm}$ between the plants within the rows. Two border rows were planted at both sides of blocks to reduce the border effects.

\section{Preparation of land}

A uniform piece of land was selected for laying out the experiment. The land was brought to the fine tilth by ploughing and harrowing.

\section{Sowing and cultural practices}

The land was prepared by ploughing followed by two cross harrowing. The basal dose of 60 $\mathrm{kg} \mathrm{N}, 60 \mathrm{~kg} \mathrm{P}_{2} \mathrm{O}_{5}$ and $40 \mathrm{~kg} \mathrm{~K}_{2} \mathrm{O}$ per hectare was applied to the whole experimental area. The remaining dose of $60 \mathrm{~kg} \mathrm{~N}$ was applied in equal two splits at 30 and 45 days after sowing. The thinning operation was carried out 20 days after sowing. The cultural practices like plant protection and weeding were followed as and when required during the crop growth period.

Observations on following twelve characters were recorded on five randomly selected plants from each plot in each replication. These plants were tagged before tasseling. The data were recorded on plant height $(\mathrm{cm})$, days to $50 \%$ tasselling, days to $50 \%$ silking, days to $75 \%$ brown husk, ear height $(\mathrm{cm})$, leaf width $(\mathrm{cm})$, tassel length $(\mathrm{cm})$, cob length with husk $(\mathrm{cm})$, cob length without husk $(\mathrm{cm})$, cob diameter $(\mathrm{cm}), 100$ seed weight $(\mathrm{g})$, and grain yield per plant $(\mathrm{g})$.

\section{Statistical analysis}

\section{Analysis of variance (ANOVA)}

The analysis of variance was done as suggested by Panse and Sukhatme (1985) in following form.

\begin{tabular}{llll}
\hline $\begin{array}{l}\text { Source of } \\
\text { variation }\end{array}$ & DF & MSS & $\begin{array}{l}\text { Expected } \\
\text { mean } \\
\text { square }\end{array}$ \\
Replication & $(\mathrm{r}-1)$ & $\mathrm{MSr}$ & $\sigma^{2} \mathrm{e}+\mathrm{t} \sigma^{2} \mathrm{r}$ \\
Treatment & $(\mathrm{t}-1)$ & $\mathrm{MSt}$ & $\sigma^{2} \mathrm{e}+\mathrm{r} \sigma^{2} \mathrm{r}$ \\
Error & $(\mathrm{r}-1)$ & $\mathrm{MSe}$ & $\sigma^{2} \mathrm{e}$ \\
& $(\mathrm{t}-1)$ & & \\
Total & $(\mathrm{rt}-1)$ & & \\
\hline
\end{tabular}


Where,

$\mathrm{r}=$ number of replication

$\mathrm{t}=$ number of treatments

\section{Results and Discussion}

The mean values, range, standard error and $\mathrm{CV}$ of the thirty genotypes for different characters are given in Table 1.

\section{Plant height (cm)}

The genotype CML-161 (74.63 cm) was found dwarf, while HUZM-185 $(163.92 \mathrm{~cm})$ was found tall. The observed mean value was $134.09 \pm 3.98$ and C.V. was $5.15 \%$.

\section{Days to $50 \%$ tasseling}

The days to $50 \%$ tasseling ranged from 42.67 (HUZM-478) to 57.33 (HUZM-53) and overall mean performance was $51.86 \pm 2.24$ whereas, the C.V. was $7.49 \%$.

\section{Days to 50\% silking}

The days to $50 \%$ silking range was from 48.33 (HUZM-478) to 64.33 (HUZM-53) and with mean value being $58.43 \pm 2.37$ while, C.V. was $7.00 \%$.

\section{Days to $75 \%$ brown husk}

The days to $75 \%$ brown husk ranged from 76.00 (HUZM-478) to 97.33 (HUZM-53) whereas, overall mean value was $88.88 \pm 2.39$ and C.V. was $4.66 \%$.

\section{Ear height (cm)}

The ear height was varied from $30.01 \mathrm{~cm}$ (CML-169) to $64.70 \mathrm{~cm}$ (HUZM-185) and overall means value was found $51.98 \pm 1.98$ and C.V. was $6.60 \%$.

\section{Leaf width $(\mathrm{cm})$}

The leaf width range of means was from 6.48 cm (CML-161) to $11.08 \mathrm{~cm}$ (HKI-162). The value of grand mean was found $8.56 \pm 0.20$ and C.V. was $4.03 \%$.

\section{Tassel length $(\mathrm{cm})$}

For the tassel length mean varied from 24.27 $\mathrm{cm}$ (CML-163) to $37.14 \mathrm{~cm}$ (HKI-287), whereas, grand mean was found $30.94 \pm 1.52$ and C.V. was $8.51 \%$.

\section{Cob length with husk (cm)}

For this trait, the mean value was varying from $18.41 \mathrm{~cm}$ (HUZM-88) to $30.91 \mathrm{~cm}$ (HUZM-185). The value of overall mean was found to be $25.72 \pm 1.35$ and C.V. was $9.11 \%$.

\section{Cob length without husk (cm)}

For this trait, the mean value was varying from $12.43 \mathrm{~cm}$ (HUZM-88) to $21.17 \mathrm{~cm}$ (HUZM-185). The value of overall mean was found to be $17.44 \pm 2.66$ and C.V. was $9.05 \%$.

\section{Cob diameter (cm)}

For this trait, the mean value was varying from $3.78 \mathrm{~cm}$ (HUZM-536) to $5.78 \mathrm{~cm}$ (HUZM-211-1). The value of overall mean was found to be $4.38 \pm 0.23$ and C.V. was $9.09 \%$.

\section{0 seed weight $(g)$}

100 -seed weight ranged from $15.39 \mathrm{~g}$ (HUZM-88) to 20.5g (HUZM-185). The value of grand mean was found $17.35 \pm 0.41$ and C.V. was $4.06 \%$. 
Table.1 Mean performance of thirty genotypes for twelve characters studied in maize

\begin{tabular}{|c|c|c|c|c|c|c|c|c|c|c|c|c|c|}
\hline Sr No & Genotypes & $\mathbf{P H}$ & DTT & DTS & DBH & $\mathbf{E H}$ & $\mathbf{L W}$ & TL & CLWH & CLWOH & CD & $100 \mathrm{SW}$ & GY \\
\hline 1 & CML-163 & 84.57 & 50.00 & 54.67 & 84.67 & 33.48 & 7.02 & 24.27 & 26.19 & 17.68 & 4.11 & 16.13 & 72.23 \\
\hline 2 & CML-169 & 77.33 & 51.00 & 56.67 & 86.00 & 30.01 & 7.18 & 31.73 & 25.14 & 16.32 & 3.86 & 18.12 & 82.33 \\
\hline 3 & DMR-QPM-58 & 126.18 & 54.00 & 59.00 & 87.67 & 47.79 & 8.03 & 32.18 & 24.89 & 16.74 & 4.48 & 17.05 & 82.42 \\
\hline 4 & CML-141 & 89.21 & 50.67 & 57.33 & 87.33 & 36.26 & 6.74 & 30.74 & 26.59 & 18.80 & 4.25 & 17.71 & 81.47 \\
\hline 5 & CML-161 & 74.63 & 50.67 & 60.00 & 90.33 & 30.46 & 6.48 & 27.54 & 24.87 & 17.00 & 4.71 & 16.95 & 81.91 \\
\hline 6 & HKI-162 & 137.79 & 55.00 & 61.33 & 91.00 & 57.01 & 11.08 & 31.03 & 26.22 & 17.99 & 4.05 & 17.08 & 87.45 \\
\hline 7 & HKI-164-4-(1-3)-2 & 103.55 & 51.33 & 59.67 & 88.33 & 43.18 & 8.67 & 32.88 & 25.06 & 17.02 & 4.27 & 18.04 & 83.30 \\
\hline 8 & HUZM-53 & 162.40 & 57.33 & 64.33 & 97.33 & 62.95 & 8.62 & 29.39 & 25.82 & 17.90 & 4.36 & 15.41 & 100.73 \\
\hline 9 & HUZM-88 & 155.10 & 52.00 & 58.33 & 88.33 & 60.21 & 8.56 & 29.52 & 18.41 & 12.43 & 4.47 & 15.39 & 70.33 \\
\hline 10 & HUZM-97-1-2 & 83.40 & 52.67 & 59.67 & 90.00 & 31.46 & 9.32 & 33.49 & 23.53 & 16.20 & 4.32 & 17.06 & 90.41 \\
\hline 11 & HKI-193-1 & 146.02 & 52.67 & 61.00 & 91.00 & 53.82 & 8.04 & 30.05 & 26.02 & 18.33 & 4.30 & 18.11 & 86.33 \\
\hline 12 & HKI-287 & 143.94 & 53.00 & 61.33 & 92.00 & 52.45 & 8.60 & 37.14 & 26.02 & 16.73 & 4.34 & 17.43 & 88.23 \\
\hline 13 & HKI-586 & 142.20 & 52.67 & 57.67 & 89.00 & 53.02 & 9.35 & 29.16 & 23.69 & 15.51 & 4.32 & 17.55 & 84.58 \\
\hline 14 & HUZM-152 & 124.81 & 51.33 & 56.67 & 87.33 & 52.43 & 8.71 & 29.22 & 25.53 & 17.30 & 4.65 & 18.02 & 88.12 \\
\hline 15 & HUZM-185 & 163.92 & 52.67 & 61.00 & 91.67 & 64.70 & 9.25 & 30.81 & 30.91 & 21.17 & 4.51 & 20.50 & 96.22 \\
\hline 16 & HUZM-211-1 & 155.19 & 51.00 & 58.67 & 89.00 & 63.43 & 8.60 & 29.99 & 26.58 & 16.90 & 5.78 & 16.88 & 87.88 \\
\hline 17 & $\mathrm{~V}-25$ & 151.12 & 52.67 & 59.67 & 89.67 & 60.49 & 8.62 & 30.18 & 26.25 & 16.96 & 4.29 & 16.75 & 88.12 \\
\hline 18 & $V-335$ & 114.86 & 53.33 & 59.00 & 89.67 & 43.10 & 8.65 & 32.29 & 25.98 & 17.70 & 4.46 & 17.76 & 87.49 \\
\hline 19 & $V-336$ & 107.36 & 53.33 & 59.00 & 89.33 & 43.43 & 8.61 & 29.15 & 24.41 & 16.32 & 4.39 & 17.19 & 91.78 \\
\hline 20 & HUZM-242 & 155.00 & 50.67 & 56.00 & 87.00 & 60.56 & 8.20 & 32.90 & 26.19 & 18.19 & 4.25 & 17.90 & 87.07 \\
\hline 21 & HUZM-478 & 151.57 & 42.67 & 48.33 & 76.00 & 59.38 & 8.56 & 33.71 & 25.80 & 16.31 & 4.20 & 18.22 & 87.49 \\
\hline 22 & HUZM-509 & 149.91 & 45.67 & 52.00 & 83.33 & 56.96 & 8.99 & 28.62 & 25.72 & 17.43 & 4.42 & 17.34 & 85.07 \\
\hline 23 & HUZM-536 & 143.16 & 50.33 & 56.67 & 88.33 & 50.37 & 8.88 & 30.87 & 26.09 & 17.80 & 3.78 & 16.47 & 84.05 \\
\hline 24 & HUZM-1105 & 159.95 & 53.00 & 57.67 & 91.00 & 59.66 & 8.92 & 31.07 & 26.07 & 17.16 & 4.35 & 17.18 & 87.31 \\
\hline 25 & V-348 & 156.25 & 53.33 & 60.00 & 91.67 & 59.88 & 8.90 & 33.62 & 26.22 & 18.20 & 4.43 & 17.85 & 88.91 \\
\hline 26 & V-351 & 156.49 & 51.67 & 57.00 & 86.33 & 62.49 & 8.73 & 32.02 & 25.42 & 17.71 & 4.72 & 17.14 & 88.43 \\
\hline 27 & HUZM-80-1 & 148.70 & 53.33 & 60.33 & 91.00 & 57.02 & 8.86 & 31.25 & 27.67 & 19.51 & 4.33 & 17.16 & 88.57 \\
\hline 28 & HKI-1105 & 156.11 & 51.33 & 58.33 & 89.67 & 58.68 & 9.01 & 31.25 & 27.01 & 18.84 & 4.41 & 17.11 & 87.12 \\
\hline 29 & HKI-323 & 148.16 & 54.00 & 61.00 & 91.00 & 57.02 & 8.89 & 31.25 & 26.15 & 17.95 & 4.29 & 17.96 & 85.68 \\
\hline \multirow[t]{6}{*}{30} & HUZM-60 & 153.89 & 52.33 & 60.67 & 91.33 & 57.60 & 8.76 & 31.26 & 27.02 & 19.10 & 4.33 & 17.17 & 87.55 \\
\hline & Mean & 134.09 & 51.86 & 58.43 & 88.88 & 51.98 & 8.56 & 30.94 & 25.72 & 17.44 & 4.38 & 17.35 & 86.29 \\
\hline & Range Lowest & 74.63 & 42.67 & 48.33 & 76.00 & 30.01 & 6.48 & 24.27 & 18.41 & 12.43 & 3.78 & 15.39 & 70.33 \\
\hline & Range Highest & 163.92 & 57.33 & 64.33 & 97.33 & 64.70 & 11.08 & 37.14 & 30.91 & 21.17 & 5.78 & 20.50 & 100.73 \\
\hline & S.E. & 3.98 & 2.24 & 2.37 & 2.39 & 1.98 & 0.20 & 1.52 & 1.35 & 2.66 & 0.23 & 0.41 & 3.62 \\
\hline & C.V. & 5.15 & 7.49 & 7.00 & 4.66 & 6.60 & 4.03 & 8.51 & 9.11 & 9.05 & 9.09 & 4.06 & 7.26 \\
\hline
\end{tabular}


Table.2 Analysis of Variance (ANOVA) for twelve traits in thirty maize genotypes

\begin{tabular}{|c|c|c|c|c|c|c|c|c|c|c|c|c|c|}
\hline \multirow{2}{*}{$\begin{array}{l}\text { Source of } \\
\text { variation }\end{array}$} & \multirow[t]{2}{*}{ DF } & \multicolumn{12}{|c|}{ Mean sum of squares } \\
\hline & & $\mathbf{P H}$ & DTT & DTS & DBH & EH & $\mathbf{L W}$ & $\mathbf{T L}$ & CLWH & CLWOH & CD & $100 \mathrm{SW}$ & GY \\
\hline Replication & 2 & 194.49 & 11.54 & 13.30 & 14.21 & 18.03 & 0.33 & 13.61 & 7.36 & 0.06 & 0.49 & 1.16 & 61.71 \\
\hline Treatment & 29 & $2396.89^{* *}$ & $20.59^{* *}$ & $27.70^{* *}$ & $38.33^{* *}$ & $341.58^{* *}$ & $2.24^{* *}$ & $15.74^{* *}$ & $10.75^{* *}$ & $6.62^{* *}$ & $0.33^{* *}$ & $2.60^{* *}$ & $2.60^{* *}$ \\
\hline Error & 58 & 47.62 & 15.08 & 16.76 & 17.13 & 11.78 & 0.12 & 6.93 & 5.49 & 2.49 & 0.16 & 0.49 & 0.49 \\
\hline
\end{tabular}




\section{Grain yield per plant (g)}

The grain yield per plant was found lowest for HUZM-88 (70.33g) and highest for genotype HUZM-53 (100.73g) with $86.29 \pm 3.62 \mathrm{~g}$ being the mean value and C.V. was $7.26 \%$ for this character.

\section{Analysis of variance}

The analysis of variance for the design of an experiment (Table-2) indicated the existence of significant variability among the 30 genotypes of maize for all the characters under study. The presence of large amount of variability is due to diverse source of the material as well as environmental influence, which pre-dominantly governed the phenotype.

The variability was highly significant for all the traits of the genotypes. Thus, the presence of variability in present investigation indicated the ample scope of selection for these traits. Similar trends of high significant difference among the different genotypes were observed by Parimala et al., 2011, Pinnisch et al., 2012 and Patil et al., 2016 in maize and Jakhar et al., 2016 in chickpea in previous studies.

\section{References}

Downsell, C.R., Paliwal, R.L., Cantrell, R.P. 1996. Maize in the third world. West view press, pp. 1-37.

Jakhar, D.S., Kamble, M.S., Singh, A., Kumar, S. 2016. Performance of chickpea genotypes in Kolhapur region. International Journal of Agriculture, Environment and Biotechnology, 9(2): 283-289.

Panse, V.G., Sukhatme, P.V. 1985. Statistical Methods for Agricultural Workers, Indian Council of Agricultural Research, New Delhi.

Parimala, K., Raghu, B., Reddy, A.V. 2011. Correlation and path analysis for yield and quality traits in maize (Zea mays L.). Plant Arch., 11(2): 1045-1047.

Patil, S.M., Kumar, K., Jakhar, D.S., Rai, A., Borle, U.M., Singh, P. 2016. Studies on variability, heritability, genetic advance and correlation in maize (Zea mays L.). International Journal of Agriculture, Environment and Biotechnology, 9(6): 1103-1108.

Pinnisch, R., Mowers, R., Trumpy, H., Walejko, R., Bush, D. 2012. Evaluation of maize (Zea mays L.) inbred lines for yield component traits and kernel morphology. Maydica, 57: 1-5.

\section{How to cite this article:}

Dan Singh Jakhar, Rajesh Singh, Aneesh Kumar Chandel, Chandan Kumar and Vivek Kumar Ojha. 2017. Mean Performance and Analysis of Variance of Thirty Genotypes for Twelve Characters Studied in Maize (Zea mays L.). Int.J.Curr.Microbiol.App.Sci. 6(4): 2782-2787. doi: https://doi.org/10.20546/ijcmas.2017.604.321 